\title{
Analysis of Copra and Coconut Oil Markets in Mexico
}

\author{
Lagunes-Fortiz, Edgar R. ${ }^{1}$; Gómez-Gómez, Alma A. ${ }^{1^{*}}$; Leos-Rodríguez, Juan A. ${ }^{2}$; \\ Omaña-Silvestre, José Miguel ${ }^{3}$; Lagunes-Fortiz, Erika ${ }^{4}$
}

\begin{abstract}
${ }^{1}$ Universidad Autónoma Chapingo. División de Ciencias Económico Administrativas. Texcoco, Estado de México. ${ }^{2}$ Universidad Autónoma Chapingo. Centro de Investigaciones Económicas, Sociales y Tecnológicas de la Agroindustria y la Agricultura Mundial. Texcoco, Estado de México. ${ }^{3}$ Colegio de Posgraduados Campus Montecillos. Texcoco, Estado de México. ${ }^{4}$ Universidad Autónoma Chapingo. Departamento de Fitotecnia. Texcoco, Estado de México.
\end{abstract}

*Corresponding author: almaaliciamx@yahoo.com

\begin{abstract}
Objective: To assess the economic impact of the implementation of different production systems (real, traditional, intensive and organic) on the profits of copra-producing states and major coconut oil companies.

Design/Methodology/Approach: A linear programming model was formulated which considered the main costs and production revenues, and the transport costs of the copra and coconut oil market, in order to maximize the profit of copra producers and the oil industry simultaneously.

Results: The states that were most suitable in the distribution of copra were Guerrero and Tabasco, which proved to be the main suppliers of all the production systems evaluated; within production systems, the intensive system presented a higher level of profit in the scenarios raised

Study Limitations/Implications: The model considered the sale of copra as the sole income of producers, leaving aside the marketing of other products and economic transfers, thus underestimating their total profit. Future research is required to help collect data on alternative sources of income for producers.

Findings/Conclusions: Increasing copra production without taking into account the installed capacity in the industry results in the creation of a copra surplus in most producing states, which would result in a fall in the prices of this product, therefore reducing the profit of most states.
\end{abstract}

Keywords: Spatial equilibrium Model, Profit Maximization, Production Planning.

\section{INTRODUCTION}

Copra

is an agricultural product obtained from the drying of coconut pulp,

on which a large number of industries depend, the most important of which is coconut oil (Granados and Lopéz, 2002). This crop is of special importance for the states of Guerrero, Colima and Tabasco, where more than $90 \%$ of the national production is concentrated, which in 2018 reached a value of 1,949.28 million pesos in those states (SIAP, 2019). However, during the last decades, national copra production has been negatively affected by different factors such as: advanced age of the plantations; diseases such as lethal coconut

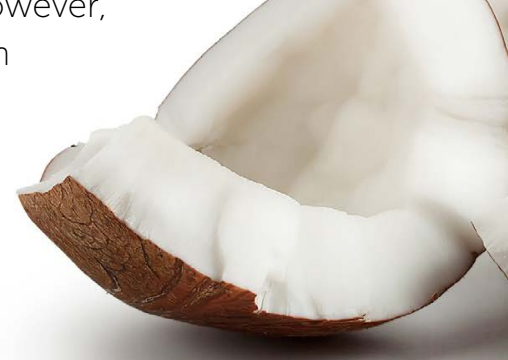


yellowing; low investment and use of inefficient agricultural practices, which have led to low yields in the plantations (INIFAP, 2019).

According to the United States Department of Agriculture (USDA, 2019). Mexico is the eighth largest consumer of coconut oil worldwide. This consumption, because of the low productivity of the copraproducing sector and the limited capacity of the agroindustry to produce coconut oil domestically, has meant that consumption has been satisfied thanks to imports that come mainly from the United States, which in 2017 reached 86,864 tons. In recent years, coconut oil imports have shown a growing trend due to increased demand and stagnation of domestic production (SIAVI, 2020). Although copra has a growing market (SAGARPA, 2017), the real price has stagnated at $\$ 6,638.00$ pesos (MX) per ton during the period 2012-2017, so that many producers have decided to abandon or change the crop, putting at risk the agrifood and cosmetic industry that depends on this product. As a result, different organizations such as: Institutional Fund for Regional Promotion of Scientific, Technological and Innovation Development (Fondo Institucional de Fomento Regional para el Desarrollo Científico, Tecnológico y de Innovación, FORDECYT, 2018); the House of Representatives in conjunction with the National Council of Science and Technology (Consejo Nacional de Ciencia y Tecnología, CONACYT, 2015); the Ministry of Agriculture, Livestock, Rural Development, Fisheries and Food (Secretaría de Agricultura, Ganadería, Desarrollo Rural, Pesca y Alimentación, SAGARPA, 2010); the National Institute of Forestry, Agricultural and Livestock Research (Instituto Nacional de Investigaciones Forestales, Agrícolas y Pecuarias, INIFAP, 2015); have set themselves the task of looking for alternatives that will have a positive impact on profits from producers, the main one being to increase production directly through the application of new techniques.

In order to solve problems related to production optimization, several studies have been carried out where spatial equilibrium models have been applied, for example: the study conducted to analyze the effects of the North American Free Trade Agreement on tomato exports from Mexico to the United States, and the impact that the application or elimination of foreign trade instruments such as tariffs would have (Garcia, Williams and Malaga, 2015); the work carried out to analyze the optimal temporal and spatial storage of sorghum in Mexico (Rebollar, García and Rodríguez, 2006); the study focused on the analysis of the bean market, in which the structure of the bean market in Mexico was determined through the application of a spatial equilibrium model (Torres and Garcia, 2008); and the mathematical model to improve the distribution of prickly pear for Mexico through the minimization of costs of transportation routes from producing to consuming areas, obtaining the optimal distribution to market it (Ayllon et al., 2015).

The importance of copra cultivation lies in the large number of hectares dedicated to this crop, the byproducts obtained from its industrialization, and the jobs that depend directly and indirectly on the national copra-producing sector. The objective of this study was to evaluate how policies aimed at increasing copra production at the field level would impact the profits of copra producers and coconut oil companies, analyzing the functioning of the copra and coconut oil markets together.

\section{MATERIALS AND METHODS}

A linear programming model (Badole and Jain, 2012) was formulated for the distribution of the copra and coconut oil market, in order to analyze the coconut oil market and to determine how agents would respond to the proposed scenarios. The model takes into account the economic variables that determine the main revenues and costs of economic agents; it is a spatial equilibrium model (Takayama and Judge, 1971), similar to the linear programming model for the maximization of profits of prickly pear producers through optimization in the distribution network for the supply chain (GranilloMacias et al., 2019). It seeks to optimize the profit of coconut producers and companies dedicated to coconut oil production, maximizing the income of copra producers and national oil companies simultaneously, and minimizing the value of the costs of copra production, oil processing, transportation, as well as the costs of acquiring and distributing coconut oil imports from the borders to the states of consumption.

The model considered four different types of technology in copra production: real, which is the one observed in official sources; traditional, which is the one that is carried out using few technical and technological advances; intensive, which uses advances in techniques and products, such as agrochemicals and improved palms; and organic, which uses improvements in agricultural 
techniques, but is free from the use of synthetic agrochemicals.

Formulation of the market profit maximization model

$$
\begin{gathered}
\operatorname{Max} f(x)=\sum_{i=1}^{n} p_{i j}^{\alpha} x_{i j}^{\alpha}-\sum_{i=1}^{n} \sum_{i=1}^{n} t_{i j}^{\alpha} x_{i j}^{\alpha}-\sum_{i=1}^{n} c_{i j}^{\alpha} x_{i j}^{\alpha} \\
+\sum_{i=1}^{n} p_{j k}^{\beta} x_{j k}^{\beta}-\sum_{j=1}^{n} \sum_{k=1}^{n} t_{j k}^{\beta} x_{j k}^{\beta}-\sum_{j=1}^{n} c_{j}^{\beta} x_{j k}^{\beta} \\
-\sum_{l=1}^{n} \sum_{k=1}^{n} p_{l k}^{\beta} x_{l k}^{\beta}-\sum_{l=1}^{n} \sum_{k=1}^{n} t_{l k}^{\beta} x_{l k}^{\beta} \\
\sum_{j=1}^{n} x_{i j}^{\alpha} \leq x_{i}^{\alpha} \\
x_{j}^{\beta}=\sum_{j=1}^{n} x_{i j}^{\alpha} a_{i}^{\gamma \alpha} \\
x_{j}^{\beta} \leq x_{i j}^{\alpha} a_{i}^{\gamma \alpha} \\
\sum_{j=1}^{n} x_{j k}^{\beta}+\sum_{l=1}^{n} x_{l k}^{\beta} \geq y_{l}^{\beta}
\end{gathered}
$$

Where:

$p_{i j}^{\alpha}$ purchase price of copra in the purchase zone; $x_{i j}^{\alpha}$ quantity of copra produced in $i$ to be taken to $j ; t_{i j}^{\alpha}$ transportation cost per ton of copra from production zone $i$ to plant $j ; c_{i}^{\alpha}$ copra production cost in the production zone; $p_{j k}^{\beta}$ purchase price of coconut oil produced at the national level; $x_{j k}^{\beta}$ quantity of coconut oil produced at production plant $k$ that will be taken to state $k_{i} t_{j k}^{\beta}$ transportation cost per ton of coconut oil from production plant $j$ to consumption center $k_{i} c_{j}^{\beta}$ cost of transformation of copra to coconut oil at plant $j ; x_{l k}^{\beta}$ imported quantity of coconut oil at border $/$ that will be taken to state $k ; p_{l k}^{\beta}$ acquisition price of coconut oil at the border; $t_{l k}^{\beta}$ transportation cost per ton of coconut oil from border $/$ to consumption center $k$; $a_{i}^{\gamma \alpha}$ transformation rate from copra to coconut oil.

\section{Assuming:}

$i=1,2 \ldots l=12$ copra-producing regions; $j=1,2 \ldots J=7$ coconut oil producing plants; $l=1,2=2$ ports of entry for coconut oil imports; $k=1,2 \ldots 32=32$ coconut oil consumption centers.

Equation (1) is the profit maximization function of the domestic market, which is obtained by subtracting the costs of production, processing and transportation from the income from the sale of copra and coconut oil produced in the territory; the cost of purchasing and transporting coconut oil from abroad was also considered.
The objective function is restricted by four equations described next:

Equation (2) establishes that the sum of copra shipments from the production zone to the oil processing plants should not be greater than their production; if the plants' demand is satisfied or it is not possible to produce more oil, the surplus production remains in these regions.

Equation (3) indicates that the amount of coconut oil that domestic plants offer is equal to the transformation coefficient (the amount of copra needed to produce one ton of coconut oil) multiplied by the amount of copra they demanded from copra-producing regions; this restriction implies that the plants cannot function as product warehouses.

Equation (4) establishes that the oil supply of the companies should be less than or equal to the installed capacity of the plants; that is, the plants cannot sell more coconut oil than they are able to produce on their own.

Equation (5) shows how coconut oil is distributed, the sum of the shipments of coconut oil produced in the companies at the national level and imported at the possible borders should be greater than or equal to the demand of each consumer state; this restriction shows that no demand should be left unsatisfied.

To feed the model, the quantities produced, different costs and prices during 2017 were considered. The quantities of copra produced were compiled from the main copraproducing states in Mexico, and were disaggregated by municipality in the case of Colima, since Tecomán is located in this state, which is the municipality with the largest production in the country. The model has 12 production regions; production for traditional, intensive and organic production technologies was obtained by multiplying the calculated yield of these technologies by the area of copra available in the state or municipality (Table 1).

According to data from the National Statistical Directory of Economic Units (Directorio Estadístico Nacional de Unidades Económicas, DENUE, 2019), in Mexico the leading companies in coconut oil processing are: Calahua (Lerma, State of Mexico); A de Coco (Armería, Colima); San Lucas (Iztacalco, CDMX); Campo Vivo (Colima, Colima); Soy de Aceite (Zapopan, Jalisco); DEICOCO (Tecomán, Colima) and ICOSA (Miguel 


\begin{tabular}{|c|c|c|c|c|}
\hline Producer region & Real production & Trational production & Intensive production & Organic production \\
\hline Campeche & 354.57 & 655.11 & 831.75 & 676.51 \\
\hline Chiapas & 805.10 & 3237.90 & 4110.97 & 3343.68 \\
\hline Armería & 5439.00 & 20477.84 & 25999.51 & 21146.83 \\
\hline Coquimatlán & 160.00 & 602.40 & 764.83 & 622.08 \\
\hline Ixtlahuacán & 47.00 & 176.96 & 224.67 & 182.74 \\
\hline Tecomán & 8794.00 & 33109.41 & 42037.08 & 34191.07 \\
\hline Guerrero & 187963.90 & 314393.69 & 399167.25 & 324664.72 \\
\hline Jalisco & 1317.64 & 3034.59 & 3852.84 & 3133.73 \\
\hline Michoacán & 2872.65 & 10843.20 & 13766.98 & 11197.44 \\
\hline Oaxaca & 8772.83 & 30383.55 & 38576.21 & 31376.16 \\
\hline Tabasco & 10749.51 & 47144.50 & 59856.61 & 48684.68 \\
\hline Veracruz & 1020.26 & 5677.62 & 7208.54 & 5863.10 \\
\hline Total & 228296.46 & 469736.76 & 596397.26 & 485082.74 \\
\hline
\end{tabular}

Source: Own elaboration with data from SIAP (2019), FIRA (2019), INIFAP (2019) and information from producers.

Hidalgo, CDMX), the first three being the most important because they concentrate most of the production. An installed capacity of between 30 and 21 thousand tons of oil was estimated for each, depending on their size. The transformation rate is 6 tons of oil per ton of copra, a transformation cost of 28,830 pesos per ton, which was calculated from a process of extraction by pressing, evaporation and filtering.

According to official information, there are 49 customs offices in Mexico: 19 on the northern border and 2 on the southern border, 17 maritime, 11 inland (SNICE, 2020); however, more than $95 \%$ of coconut oil imports transit through the customs offices located in Manzanillo (Colima) and Piedras Negras (Coahuila). The model made it possible to calculate the quantity of product, the destination and the routes to be taken by the imports derived from the different scenarios proposed.

To estimate the national demand for coconut oil, the 31 states and Mexico
City were considered as separate consumer regions. Apparent consumption was obtained by multiplying per capita consumption by population using official data from the National Institute of Statistics and Geography (INEGI) for 2017; an apparent consumption of $222,700.26$ tons of coconut oil at the national level was calculated.

Transportation costs were calculated, using the distance in kilometers reported between supply and demand regions by the Ministry of Communications and Transportation (Secretaría de Comunicaciones y Transporte, SCT, 2019), the costs of diesel, transport operator, toll booths and transport insurance. With this information, the transportation cost per ton of product between routes was calculated.

Regional production costs were calculated for the four types of production analyzed (real, traditional, intensive and organic), obtained by multiplying the total production of each region by the cost of producing one ton of copra. The production cost per ton reflects the prices of labor, organic and synthetic agrochemicals, and the machinery necessary for the application of agrochemicals. This information was compiled and analyzed using the methodology presented by the Agro-costs System of the Instituted Trust in Relation to Agriculture (Fideicomisos Instituidos en Relación con la Agricultura, FIRA); this methodology allows estimating agricultural production costs parametrically in a given area or region under a specific production technology (SADER, 2020).

Programming the model was carried out in the mathematical optimization package LINDO 18.0 (Cunningham and Schrage, 2004), and three scenarios were established for each technology: an increase for each state in the quantity of coconut oil demanded of $10 \%$, an increase in copra production of 10\% in each state, and an increase in the installed capacity of the companies of $10 \%$ for each. 


\section{RESULTS AND DISCUSSION}

According to the table of total revenues from the market obtained by the LINGO software, the intensive production mode is the one that generates the largest profit in all the scenarios (Table 9). Tables 2, 4 and 6 show the result of the quantities shipped from the copra-producing states to the coconut oil production plants, the surplus in regional copra production, and the profit for each production region. It should be noted that it is natural to expect a negative value in regional profits, because the model only considers the profit from the sale of copra and discards income derived from the sale of byproducts, such as coconut fiber, coconut shell, among others; the model also does not consider government economic transfers such as support and subsidies, which increase the profits of regional producers. Tables 3, 5 and 7 are the results for the coconut oil market and show the total shipments from the producing plants to the consuming states and the profits they obtain, as well as the amount and cost of imports. Finally, Table 8 presents the total profits of each type of production given the scenarios presented.

The results for the base model (where demand and installed capacity reflect current data), indicate that the states with the greatest potential for copra distribution are Guerrero and Tabasco (Table 2). This is due to the low cost of transporting copra from these states to the coconut oil producing plants. According to the base model, if the state of Guerrero increases its copra production, it would be able to satisfy the demand of several coconut oil production companies; if this happens, the states geographically close to Guerrero (especially Colima and Jalisco) would not be able to place their production in the market, which would be counterproductive for them, due to the economic importance they represent.

Regarding the coconut oil market, the base model (Table 3) shows that the principal brands are the ones that obtain a higher profit, and Campo Vivo and Soy Aceite de Coco are the ones that make the least shipments. It is remarkable that, when analyzing the traditional, intensive and organic technologies, all companies are able to produce at their peak, however, the quantities imported do not change even when there is enough copra to produce the demanded oil, so it is correct to assume that this limitation in the industry prevents the domestic coconut oil market from reaching its maximum potential.

The results for a scenario where the demand for coconut oil has a $10 \%$ increase at the national level, are very similar to those of the base model (Table 4). The states

\begin{tabular}{|c|c|c|c|c|c|c|c|c|c|c|c|}
\hline \multicolumn{12}{|c|}{ Copra market - Baseline scenario } \\
\hline \multirow[b]{2}{*}{ Region } & \multicolumn{2}{|c|}{ Real } & \multicolumn{3}{|c|}{ Traditional } & \multicolumn{3}{|c|}{ Intensive } & \multicolumn{3}{|c|}{ Organic } \\
\hline & $\begin{array}{l}\frac{n}{o} \\
\frac{c}{0} \\
\frac{0}{2} \\
\frac{c}{n}\end{array}$ & $\begin{array}{l}\frac{\pi}{0} \\
\frac{0}{0}\end{array}$ & $\begin{array}{l}\text { on } \\
\frac{c}{\circ} \\
\frac{0}{2} \\
\frac{\bar{c}}{n}\end{array}$ & $\begin{array}{l}\frac{n}{3} \\
\frac{n}{3} \\
\text { जn }\end{array}$ & $\begin{array}{l}\frac{7}{0} \\
\frac{0}{0}\end{array}$ & $\begin{array}{l}\text { on } \\
\frac{c}{0} \\
\frac{0}{\frac{c}{n}} \\
\frac{n}{n}\end{array}$ & $\begin{array}{l}\frac{n}{3} \\
\frac{0}{2} \\
\frac{3}{3}\end{array}$ & $\begin{array}{l}\text { 劳 } \\
\text { 음 }\end{array}$ & $\begin{array}{l}\frac{n}{0} \\
\frac{\overline{0}}{0} \\
\frac{0}{\frac{0}{2}} \\
\frac{n}{n}\end{array}$ & $\begin{array}{l}\frac{n}{3} \\
\frac{0}{2} \\
\frac{0}{3}\end{array}$ & $\begin{array}{l}\frac{\pi}{0} \\
\frac{0}{2}\end{array}$ \\
\hline Campeche & 354.6 & -1.8 & 0.0 & 655.1 & -3.3 & 0.0 & 831.8 & -4.1 & 0.0 & 676.5 & -4.5 \\
\hline Chiapas & 805.1 & -4.1 & 0.0 & 3237.9 & -16.1 & 0.0 & 4111.0 & -20.4 & 0.0 & 3343.7 & -22.1 \\
\hline Armería & 5439.0 & -25.4 & 0.0 & 20477.8 & -101.8 & 0.0 & 25999.5 & -129.2 & 0.0 & 21146.8 & -139.7 \\
\hline Coquimatlán & 160.0 & -0.7 & 0.0 & 602.4 & -3.0 & 0.0 & 764.8 & -3.8 & 0.0 & 622.1 & -4.1 \\
\hline Ixtlahuacán & 47.0 & -0.2 & 0.0 & 177.0 & -0.9 & 0.0 & 224.7 & -1.1 & 0.0 & 182.7 & -1.2 \\
\hline Tecomán & 8794.0 & -40.9 & 0.0 & 33109.4 & -164.6 & 0.0 & 42037.1 & -208.8 & 0.0 & 34191.1 & -225.9 \\
\hline Guerrero & 187963.9 & -914.7 & 234522.2 & 0.0 & -778.7 & 221810.1 & 87856.8 & -1206.1 & 232982.0 & 2182.3 & -1340.3 \\
\hline Jalisco & 1317.6 & -6.3 & 0.0 & 0.0 & -7.4 & 0.0 & 3852.8 & -19.1 & 0.0 & 3133.7 & -20.7 \\
\hline Michoacán & 2872.7 & -13.6 & 0.0 & 9926.5 & -51.5 & 0.0 & 13767.0 & -68.4 & 0.0 & 11197.4 & -74.0 \\
\hline Oaxaca & 8772.8 & -43.3 & 0.0 & 30383.6 & -151.1 & 0.0 & 38576.2 & -191.7 & 0.0 & 31376.2 & -207.3 \\
\hline Tabasco & 10749.5 & -53.3 & 47144.5 & 0.0 & -122.6 & 59856.6 & 0.0 & -155.4 & 48684.7 & 0.0 & -206.2 \\
\hline Veracruz & 1020.3 & -5.0 & 0.0 & 0.0 & -14.4 & 0.0 & 7208.5 & -35.8 & 0.0 & 5863.1 & -38.7 \\
\hline Total & 228296.4 & -1109.5 & 281666.7 & 98569.6 & -1415.4 & 281666.7 & 225230.1 & -2044.0 & 281666.7 & 113915.6 & -2284.5 \\
\hline
\end{tabular}

Source: Own elaboration with results of the Lingo program. 


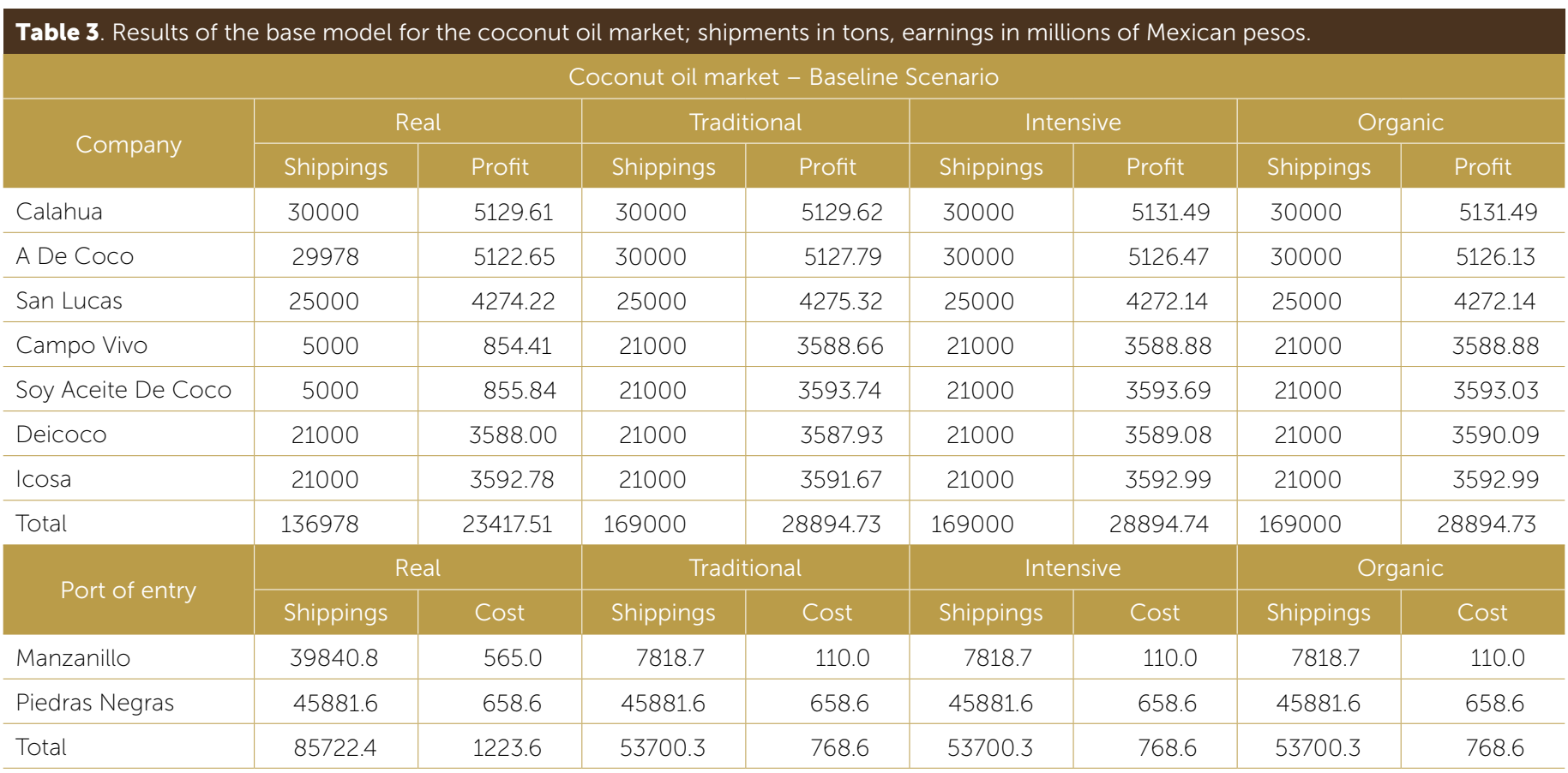

Source: Own elaboration with results of the Lingo program.

of Guerrero and Tabasco turned out to be those that have priority in the distribution of copra according to the model; it is observed that shipments from the producing states to the companies did not increase despite the increase in demand for coconut oil, due to the limited capacity in coconut processing.
For the coconut oil market, a 10\% increase in the demand for this product can be observed according to the model that all plants would work at their maximum capacity; however, domestic production would not be sufficient to meet this increase in demand, so it would be necessary to increase imports of coconut

Table 4. Results of the model for the scenario with a $10 \%$ increase in demand for the copra market; shipments and surpluses in tons, earnings in millions of Mexican pesos.

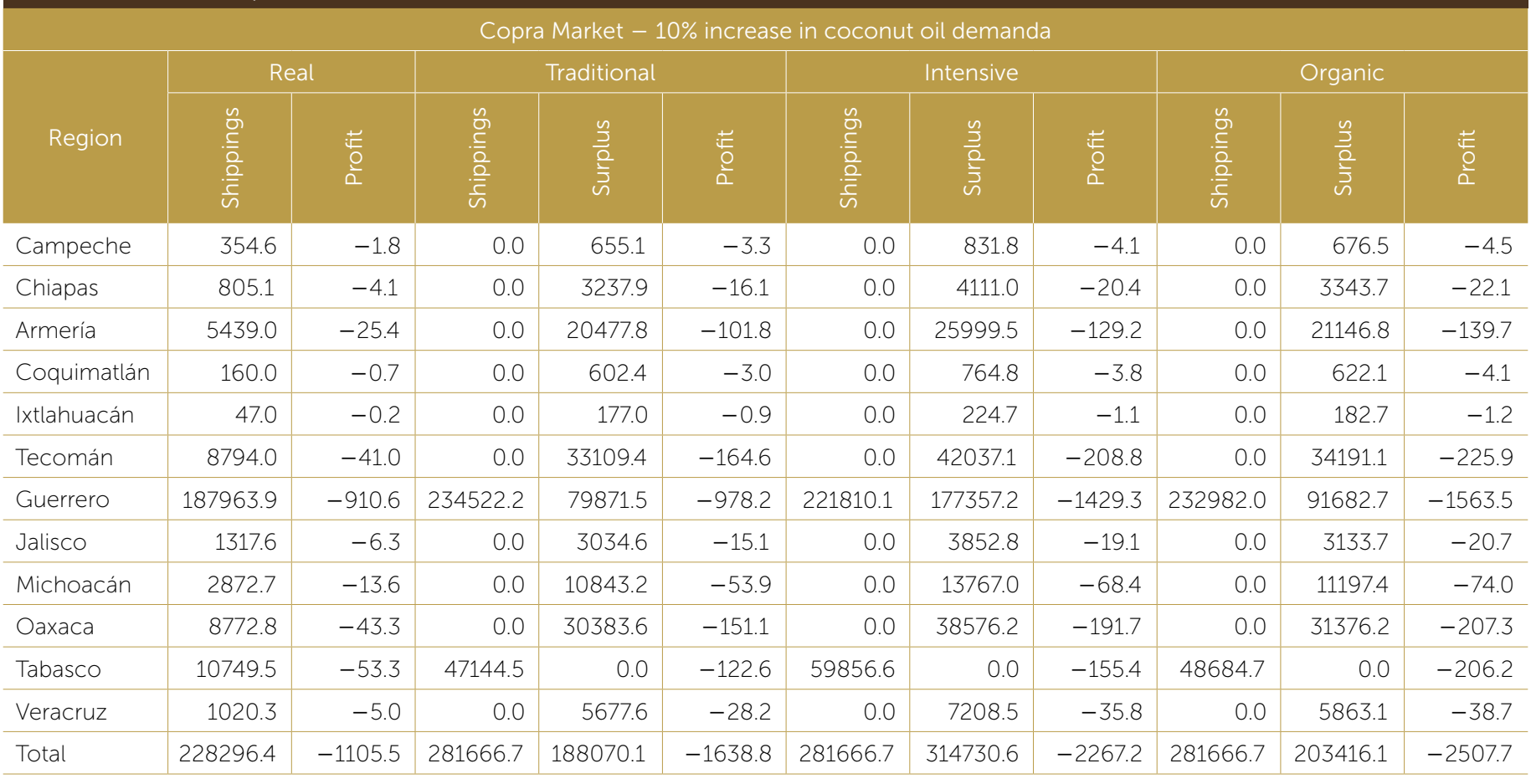

Source: Own elaboration with results of the Lingo program. 


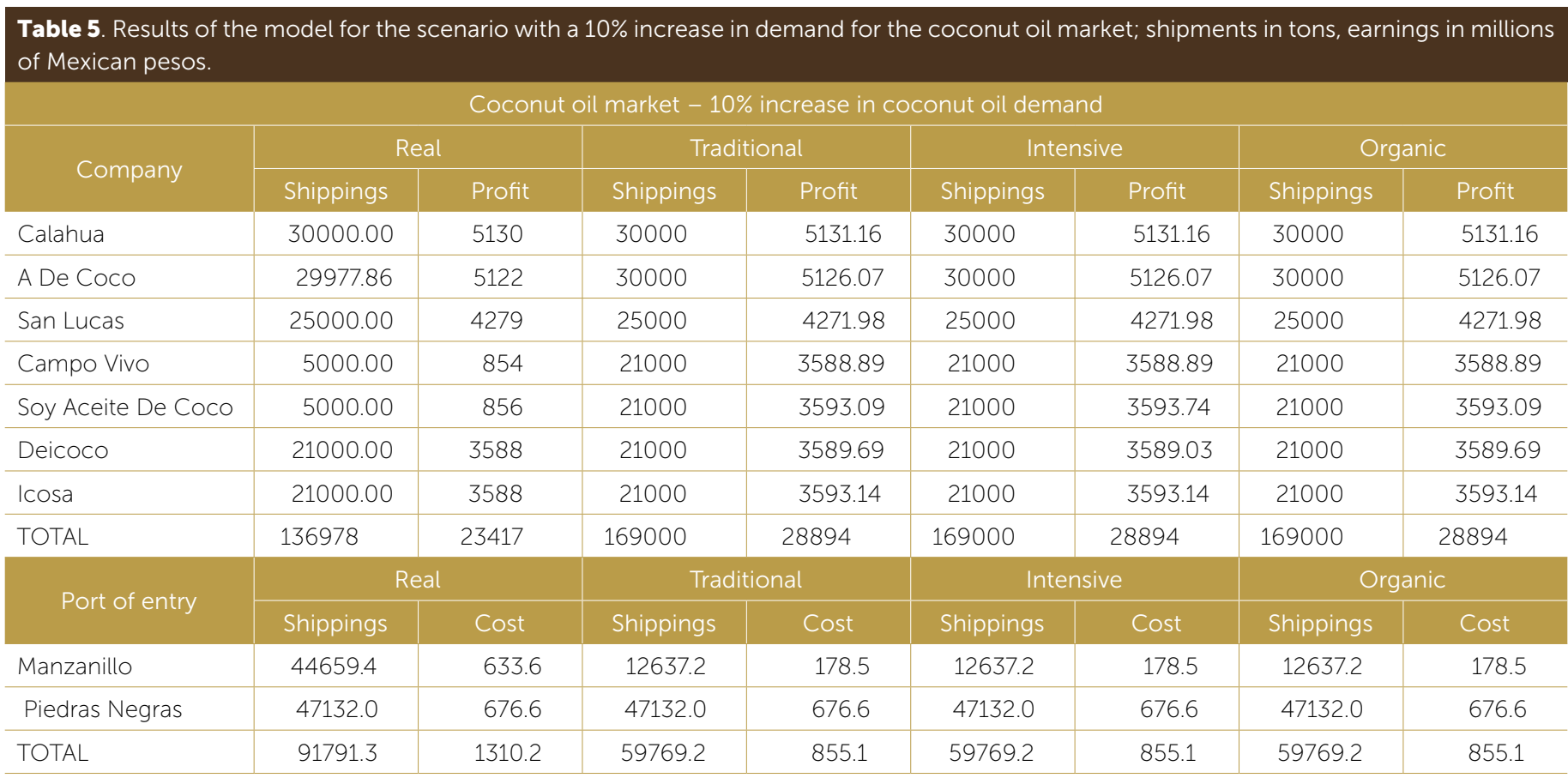

Source: Own elaboration with results of the Lingo program.

oil, reducing the potential gain of the market (Table 5). When compared to the previous situation, the model indicates that an increase in the demand for coconut oil is detrimental in all scenarios, despite the increase in copra production resulting from the application of more efficient techniques.

According to the results of the model, with a $10 \%$ increase in the production capacity of coconut oil for each company in the market, the results show that: for the real production where the current situation is reflected, the results are the same as for Table 3. In the case of traditional technology, copra-producing states near the coconut oil companies manage to distribute part of their production, these being the states of Jalisco, Michoacán and Veracruz, because the states of Guerrero and Tabasco are unable to meet the demand for copra; for the other two technologies, it is observed that the

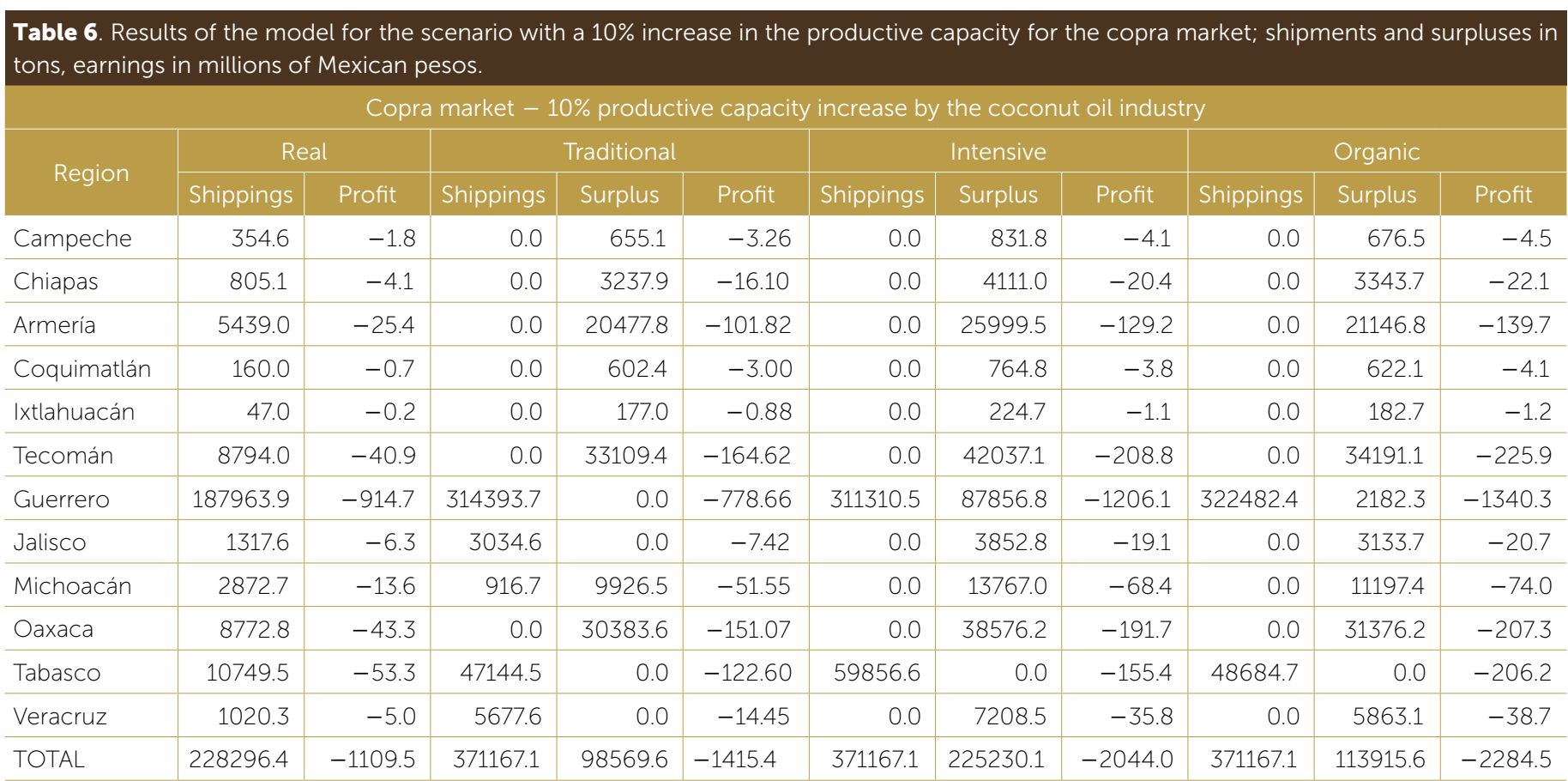

Source: Own elaboration with results of the Lingo program. 
states of Guerrero and Tabasco alone are capable of meeting this demand (Table 6).

Finally, for the coconut oil market, with a $10 \%$ increase in the production capacity of domestic companies, it is observed that for the scenarios where copra production increases in the states (traditional, intensive and organic production), the plants are capable of supplying the domestic market completely, eliminating the need to import coconut oil to satisfy domestic demand. This has resulted in an improvement of the situation of the copra and coconut oil market as a whole (Table 7).

When analyzing the total market revenues for each scenario suggested obtained by the LINGO software (Table 8), we observe that the highest value is reached when intensive production is used together with an increase in the installed capacity of the companies; and the lowest when demand increases under a base production. This is due to the fact that a greater amount of imports is needed to satisfy the demand, which implies a higher cost in its import and distribution. It is also notable that the best results are obtained when the productive capacity is increased, with the exception of the baseline situation, which does not show significant improvement.

\section{CONCLUSIONS}

The model determined that the most suitable states for copra distribution are Guerrero and Tabasco, due to their low transportation costs toward the coconut oil production plants; this is true for all scenarios and types of production.

\begin{tabular}{|c|c|}
\hline \multicolumn{2}{|c|}{ Copra and coconut oil industry markets profits } \\
\hline Baseline scenario - Real production & 22504.83 \\
\hline Baseline scenario - Traditional production & 29254.73 \\
\hline Baseline scenario - Intensive production & 29259.47 \\
\hline Baseline scenario - Organic production & 28794.97 \\
\hline Increase coconut oil demand - Real Production Increase & 21294.63 \\
\hline Increase coconut oil demand - Traditional production & 29167.55 \\
\hline Increase coconut oil demand - Intensive production & 29172.29 \\
\hline Increase coconut oil demand - Organic production & 28707.79 \\
\hline Productive capacity increase - Real production & 22508.3 \\
\hline Productive capacity increase - Traditional production & 39546.34 \\
\hline Productive capacity increase - Intensive production & 39559.5 \\
\hline Productive capacity increase - Organic production & 38948.42 \\
\hline
\end{tabular}

Source: Own elaboration with results of the Lingo program.

\begin{tabular}{|c|c|c|c|c|c|c|c|c|}
\hline \multicolumn{9}{|c|}{ Coconut oil market - $10 \%$ productive capacity increase by the coconut oil industry } \\
\hline \multirow{2}{*}{ Company } & \multicolumn{2}{|c|}{ Real } & \multicolumn{2}{|c|}{ Traditional } & \multicolumn{2}{|c|}{ Intensive } & \multicolumn{2}{|c|}{ Organic } \\
\hline & Shippings & Profit & Shippings & Profit & Shippings & Profit & Shippings & Profit \\
\hline Calahua & 40000 & 6844.40 & 40000 & 6844.40 & 40000 & 6844.40 & 40000 & 6844.40 \\
\hline Campo Vivo & 5000 & 854.14 & 35000 & 5976.75 & 35000 & 5976.75 & 35000 & 5976.75 \\
\hline Soy Aceite De Coco & 5000 & 855.84 & 22700 & 3883.56 & 22700 & 3883.56 & 22700 & 3883.56 \\
\hline Deicoco & 21978 & 3755.70 & 25000 & 4270.58 & 25000 & 4270.58 & 25000 & 4270.58 \\
\hline Icosa & 25000 & 4277.38 & 25000 & 4275.87 & 25000 & 4275.87 & 25000 & 4275.87 \\
\hline Manzanillo & 39840.8 & 565.0 & 0.0 & 0.0 & 0.0 & 0.0 & 0.0 & 0.0 \\
\hline Piedras Negras & 45881.6 & 658.6 & 0.0 & 0.0 & 0.0 & 0.0 & 0.0 & 0.0 \\
\hline TOTAL & 85722.4 & 1223.6 & 0.0 & 0.0 & 0.0 & 0.0 & 0.0 & 0.0 \\
\hline
\end{tabular}

Source: Own elaboration with results of the Lingo program. 
When comparing the results of the profit scenarios, a higher profit is obtained when the productive capacity of the industry is increased, and this is true for three scenarios suggested (base scenario, 10\% increase in the demand for coconut oil, and 10\% increase in the productive capacity of the national oil-producing plants). Therefore, the most efficient policies for maximizing market profit are technology transfer policies, focused on increasing the productive capacity of industries, either through modernization or the creation of new companies.

When observing the base scenarios and those where the demand for coconut oil increases, regardless of the type of production (real, traditional, intensive and organic), it is possible to note the creation of copra surpluses in most states, with the exception of the states of Guerrero and Tabasco. According to the results of the model, it is concluded that policies that result in an increase in copra production at the farm level will have as a direct consequence the creation of producer surpluses in most copra-producing regions, if conditions are not created to help expand the production capacity of the coconut oil industry; if an alternative market is not found, this surplus would cause a drop in copra prices at the national level, reducing the revenues of the copra sector in most of the states dedicated to this activity.

\section{REFERENCES}

Ayllon-Benítez, J. C., Omaña-Silvestre, J. M., Sangerman-Jarquín, D. Ma., Garza-Bueno, L E., Quintero-Ramírez, J. M., \& GonzálezRazo, F. de J. (2015). Modelo de transporte en méxico para la minimización de costos de distribución de tuna (Opuntia spp.) en fresco. Revista Mexicana de Ciencias Agrícolas, 6(7), 1615-1628.

Badole, C. M., Jain, R., Rathore, A. P, \& Nepal, B. (2012). Research and opportunities in supply chain modeling: a review. International Journal of Supply Chain Management 1(3), 63-86.

CONACYT. (2015). El Panorama Mundial de la Industria del Cocotero. Consejo Nacional de Ciencia y Tecnología-Cámara de Diputados. Consultado el 30 de junio de 2020, disponible en linea en http://www3.diputados.gob.mx/camara/content/ download/332320/1181428/file/C\%200ropeza\%20-\%20 Panorama\%20Mundial\%20Cocotero.pdf

Cunningham K., \& Schrage L. (2004). The Lingo algebraic modeling language. In: Kallrath J. (18), Modelling Languages in Mathematical Optimization. Applied Optimization, 88(1) Springer, Boston, Massachusetts.

DENUE. (2019). Directorio Estadístico Nacional de Unidades Económicas. Instituto NAcional de Estadistica y Geografia. Consultado el 30 de junio de 2020, disponible en https://www inegi.org.mx/app/mapa/denue/default.aspx
FIRA. (2020). Agrocostos. Fideicomisos Instituidos en Relacion con la Agricultura, Consultado el 30 de junio de 2020, disponible en https://www.fira.gob.mx/Nd/Agrocostos.jsp

FORDECYT. (2018). Impulso a la cadena de valor del cocotero para incrementar su competitividad y contribuir al desarrollo socioeconómico en la región Pacífico Sur y otros estados productores. Fondo Institucional de Fomento Regional para el Desarrollo Científico, Tecnológico y de Innovación. Consultado el 30 de junio de 2020, disponible en https:// www.conacyt.gob.mx

García-Salazar J. A., Williams G. W., \& Javier-Malaga J. E. (2015). Efectos del TLCAN sobre las exportaciones de tomate de México a los Estados Unidos. Revista Fitotecnia Mexicana 28(4), 299-309.

Granados-Sánchez D., \& Lopéz-Ríos G.F. (2002). Manejo de la palma de coco (Cocos nucifera L.) en México. Revista Chapingo erie Ciencias Forestales y del Ambiente 8(1). 39-48.

Granillo-Macías R., González-Hernández I. J., Santana-Robles F., \& Martínez-Flores, J. L. (2019). Estrategia de centros de consolidación para la distribución de tuna en México. Revista Mexicana de Ciencias Agrícolas 10(2), 265-276.

INIFAP. (2015). Instituto Nacional de Investigaciones Forestales, Agrícolas y Pecuarias. Infraestructura para la Producción y la Comercialización en el Desarrollo Regional- Programa Estratégico Para Impulsar la Cadena de Valor del Cocotero, PRO-COCO. Consultado el 30 de junio de 2020, dispoible en https://www.gob.mx/inifap

INIFAP. (2019). Secretaría de Agricultura y Desarrollo Rural. Instituto Nacional de Investigaciones Forestales, Agricolas y Pecuarias. Consultado el 30 de junio de 2020, dispoible en https://www. gob.mx/inifap

Rebollar R. S., García-Salazar J. A., \& Rodríguez-Licea G. (2006). Análisis espacial e intertemporal sobre el almacenamiento del sorgo en México. Ciencia Ergo Sum 12(3). 245-254

SADER. (2020). Gobierno de México. Fideicomisos Instituidos en Relación con la Agricultura. Consultado el 4 de mayo de 2020 dispoible en https://www.gob.mx/fira/documentos/sistemade-agrocostos-fira

SAGARPA. (2010). Secretaría de Agricultura, Ganadería, Desarrollo Rural, Pesca y Alimentación. Programa Estratégico para el Desarrollo Rural Sustentable de La Región Sur Sureste de México-Trópico Húmedo. Consultado el 1 de junio de 2020, dispoible en https://www.gob.mx/agricultura

SAGARPA. (2017). Secretaría de Agricultura, Ganadería, Desarrollo Rural, Pesca y Alimentación. Planeación Agrícola Nacional, Palma de Coco Mexicana. Consultado el 1 de junio de 2020, dispoible en https://www.gob.mx/cms/uploads/attachment/ file/257082/Potencial-Palma_de_Coco.pdf

SCT. (2019). Rutas Punto a Punto. Secretaría de Comunicaciones y Transportes. Consultado el 15 de junio de 2020, dispobinle en http://app.sct.gob.mx/sibuac_internet/ControllerUl?action=c mdEscogeRuta

SIAP. (2019). Secretaría de Agricultura y Desarrollo Rural. Servicio de Información Agroalimentaria y Pesquera. Consultado el 11 de junio de 2020, disponible en https://www.gob.mx/siap

SIAVI. (2020). Secretaria de Economía. Sistema de Información Arancelaria Vía Internet. Consultado el 30 de junio de 2020, dispoible en http://siavi.economia.gob.mx/ 
SNICE. (2020). Secretaria de Economía. Servicio Nacional de Información de Comercio Exterior. Consultado el 15 de junio de 2020, dispoible en https://www.snice.gob.mx/

Takayama T, G G Judge. (1971). Spatial and Temporal Price and Allocation Models. Amsterdam, Holland. North-Holland, Publishing Company. 528.

Torres-Sandoval, C., \& García-Salzar, J. A. (2008). Aplicación de un modelo de equilibrio espacial para determinar la estructura del mercado de frijol en México. Revista Agrociencia, 42(6), 731-740

USDA. (2019). Oilseeds: World Markets and Trade. United States Department of Agriculture. Consultado el 30 de junio de 2020, disponible en https://usda.library.cornell.edu/?locale =en

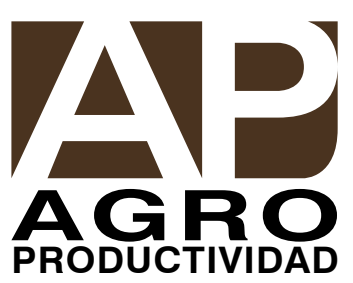

